\title{
So, Morphological Awareness Contributes to Reading in Brazilian Portuguese?
}

\author{
Pedro Viana de Freitas Junior - Universidade Salgado de Oliveira, Niterói, Brasil \\ Márcia Maria Peruzzi Elia da Mota - Universidade Salgado de Oliveira, Niterói, Brasil
}

\begin{abstract}
The present study aims to answer a recently raised controversy regarding the role that morphological awareness has to reading skills acquisition in Brazilian Portuguese. The aim was to investigate whether morphological awareness contributes to reading after controlling for non-verbal intelligence and phonological awareness in Brazilian Portuguese variables. The study included 52 elementary school students enrolled in a public school in the municipality of São Gonçalo, state of Rio de Janeiro. The hierarchical regression analyses showed that derivational morphological awareness contributes to reading independently of phonological processing and non-verbal ability. The results of this study indicate that morphological awareness contributes to reading words but not to reading comprehension. The results of this study corroborate with the hypothesis that even in an alphabetic language, such as Portuguese, morphological awareness is important to reading acquisition.

Keywords: reading, morphological awareness, literacy, non-verbal intelligence
\end{abstract}

Então, a Consciência Morfológica Contribui para a Leitura no Português Brasileiro?

\begin{abstract}
Resumo
O presente estudo tenta responder uma controvérsia levantada recentemente na literatura a respeito do papel que a contribuição da consciência morfológica exerce na aquisição da leitura no português do Brasil. Investigou se a consciência morfológica contribui para a leitura, após controlar as variáveis inteligência não verbal e consciência fonológica no português brasileiro. Participaram do estudo 52 alunos matriculados no $4^{\circ}$ e $5^{\circ}$ ano do ensino fundamental de uma escola pública do município de São Gonçalo-RJ. As análises de regressão hierárquica mostraram que o processamento morfológico derivacional contribui para leitura de forma independente do processamento fonológico e da inteligência não verbal no caso da precisão de leitura, mas não na compreensão de textos. Os resultados deste estudo sustentam a hipótese de que a consciência morfológica é uma habilidade metalinguística importante, mesmo numa língua alfabética como o português do Brasil.

Palavras-chave: consciência metalinguísticas, consciência morfológica, leitura, inteligência não verbal
\end{abstract}

Entonces, ¿ila Conciencia Morfológica Contribuye para la Lectura en el Portugués Brasileño?

\begin{abstract}
Resumen
Este estudio busca responder a una controversia recientemente levantada en la literatura, sobre el papel que la contribución de la conciencia morfológica ejerce en la adquisición de la lectura en el portugués de Brasil. Se investigó si la conciencia morfológica contribuye para la lectura, después de controlar las variables inteligencia no verbal y conciencia fonológica en el portugués de Brasil. Participaron 52 alumnos matriculados en $4^{\circ}$ y $5^{\circ}$ grado de la Enseñanza Primaria de una escuela pública del municipio de São Gonçalo-RJ. Los análisis de regresión jerárquica mostraron que el proceso morfológico derivacional contribuye hacia la lectura, independientemente del procesamiento fonológico y de la inteligencia no verbal, en el caso de la precisión lectora, pero no, en el de la comprensión de textos. Los resultados de este estudio apoyan la hipótesis de que la conciencia morfológica es una habilidad metalingüística importante, incluso en el caso de una lengua alfabética como es el caso del portugués de Brasil. Palabras clave: conciencia metalingüística, conciencia morfológica, lectura, inteligencia no verbal
\end{abstract}

Morphological awareness is the ability to intentionally think about the morphemic structure of words (Carlisle, 1995). Morphemes are the smallest units of meaning that make up words. Morphological awareness can help in reading and writing, because the spelling of many words depends on its origin; i.e., it depends on the morphology of the language (Mota, 2008).

Morphological awareness is associated with the semiographic principle, which involves establishing hat graphic units (graphemes) correspond to units of meaning (morphemes), for instance, the
(Brazilian Portuguese) word "caçador" (hunter), which has an ambiguous pelling, can be written correctly, if the learner knows its root, "caça" (hunt). The meaning of this word can also be understood in reading, if the learner knows the meaning of the root word. Thus, the relationship between graphic unit and unit of meaning of the words helps in reading and writing.

Thus, the development of morphological awareness can help in word recognition and in the identification of morphologically complex words, such as in the word "banheiro" (bathroom)in the Portuguese 
language, formed by the root word "banho" (bath) + suffix "eiro" (noun former). Therefore, it helps the learner to understand the relation between the root word and the derived word, which in turn, allows forum derstanding the meaning of the word (Deacon \& Bryant, 2005).

Besides recognizing words, there is evidence of a relationship between morphological awareness and reading comprehension. This ability is very important, especially in the higher-level grades, because the texts start to present new words with more complex spellings. Part of this word complexity is due to the morphology of the language. Studies such as those of Carlisle (1995; 2000) show that morphological awareness is associated to performance in isolated-word recognition and reading comprehension.

Thus, empirical studies have pointed out the importance of morphological awareness to reading acquisition in alphabetic languages, especially English (Carlisle, 1995; Deacon \& Kirby, 2010). Brazilian researchers also found evidence that the development of morphological awareness contributes both to word recognition and to reading comprehension in Brazilian Portuguese (Mota, Anibal \& Lima, 2008; Silva \& Mota, 2009; Mota, 2011). Furthermore, these studies show that morphological consciousness contributes to reading even after controlling for phonological awareness.

The ability to reflect on the sounds that comprise spee chis called phonological awareness. There is evidence in longitudinal studies that phonological awareness is a precursor of the development of reading and writing (Bryant \& Bradley, 1987). Studies conducted both in English and Portuguese (Mota, 2008; Deacon et al., 2008) showed that morphological awareness contributes to reading and writing, even after controlling for phonological awareness (Mota, 2008; Deacon et al., 2008).

Recently, Justi and Roazzi (2012) questioned the findings of Mota et al. (2008) about the role that morphological awareness plays in reading accuracy. The authors pointed out that Mota, Anibal, and Lima did not control an important variable in their study: intelligence. In the study by Justi and Roazzi, children in the fourth year were assessed to investigate the independent contribution of phonological processing, rapid serial naming speed, and morphological awareness for reading and writing in Brazilian Portuguese. After hierarchical regression statistical analyses with the variable sage and non-verbal intelligence, controlled, morphological awareness failed to offer significant contribution for reading accuracy and reading fluency scores. These scores contributed significantly only for writing.

The study by Justi and Roazzi (2012) raised controversy in the literature. According to the authors, when reading assignments involve words, mostly regular from the grapheme-phoneme mapping standpoint, they do not place any explicit demand to morphological knowledge. In the writing assignment conducted in the abovementioned study, the used words allowed children to benefit from the morphological awareness of the words to write them correctly. According to Justi and Roazzi, to perfectly pronounce the word "prestigioso" (prestigious) it is unnecessary to know that it derives from "prestigio" (prestige), once a graphemephoneme mapping and the mastering of contextual rules in Portuguese are enough to produce a correct pronunciation. According to the authors, the situation is different when writing the same word, because knowing that it derives from "prestigio" plus the suffix "oso" (-ous, adjective former) may help the writer to write it correctly. And, once most reading tests uses regular words, there may be some difficulty in recognizing the existence of an effect of morphological awareness while reading words that have this irregularity in the grapheme-phoneme mapping. The question raised by the authors is relevant. Therefore, although there are a number of studies showing the relationship between morphological awareness and reading, there is still need for other studies that show a further deepening of this question. The present study aims to verify the contribution of awareness for reading accuracy an dreading comprehension in Brazilian Portuguese, controlling non-verbal intelligence and phonological awareness a in a sample of students in the 4th and 5thgrades of elementary school.

In addition to the points raised above, although several studies have shown the relationship between morphological awareness and reading (Carlisle, 1995; Silva \& Mota, 2009), in Brazil there is still a shortage of studies with students from higher-level grades on this topic (Mota et al., 2011). According to Tong, Deacon, Parrila, and Kirby (2011), studies with children of higher-level grades of elementary school suggest that difficulties in morphological awareness contribute to difficulties in reading comprehension, and students with different reading comprehension profiles can learn the morphology of the language at different rates. According to the authors, children with reading comprehension difficulties have a specific deficiency in the ability to recognize morphemes, which is strongly implicated in reading. 


\section{Method}

\section{Participants}

The sample included 52 students who were attending the4th and 5thgrades of elementary school, both regularly enrolled in a public school in the municipality of São Gonçalo, state of Rio de Janeiro. The age range was $9-13$ years, with mean of 10.9 years (standard deviation 1.0 years). Among these 52 students, 26 were female and 26 male.

\section{Instruments}

\section{Reading Assessment}

1. School Performance Test (Teste de Desempenho Escolar - TDE) (Stein, 1994)

The items of isolated-word reading of the School Performance Test were administered to verify reading performance. Students were instructed to read, aloud, a set of 70 isolated words. The instrument presents evidence of criterion validity, good internal consistency $(\alpha$ $>0.70)$, and confidence level (0.99). The subtest was administered and corrected according to instructions and proceedings specified in the manual.

\section{Cloze Test (Santos, 2005)}

Thistechniqueaims to assess reading comprehension and to measure the intelligibility level of the text. Cloze consists of a text from which some words are suppressed, asking the reader to fill in the blanks with the words that best complete the meaning of the text. For the present study we selected two texts, whose psychometric properties had already been established in a previous Brazilian study (Santos, 2005). Therefore, both texts had already been verified for evidence of validity and good internal consistency $(\alpha>0.70)$. The number of possible correct answers for each text was 15 , totaling 30 points when considered both stories.

\section{Reading Comprehension Questionnaire}

In this activity we used a questionnaire for students from 11 to 14 years, with open questions related to the text "Os lápis de cor são só meus" (the crayons are mine only), from Ruth Rocha adapted by Moura (2006). The questionnaire aims to observe the basic processes for text comprehension, consisting of 14 questions divided into four questions related to macro-structure, four related to argumentation, three related to details, and three related to inference. The instrument presents reliability coefficients and good internal consistency index $(\alpha>0.71)$. For correction, the following criteria were used: one point for each correct answer.
Morphological Awareness Assessment

1. Grammatical Analogy Task (adapted from Nunes, Bindman \& Bryant, 1997)

This task verifies the student's ability to manipulate morphemes. It was adapted to the specificities of derivational morphology in the Portuguese language. For this purpose, eight items were created. In each, the student should be able to form a morphologically complex word after hearing the target word. It was applied as follows: we asked the student to, after hearing a word, create another word related to the example. From a target word, applying the same relationship, for instance, "claro-clareza; belo-??" (clear-clarity; beautiful-? $)$, and so the other target words were pronounced successively. The instrument in question presents reliability coefficients and good internal consistency index $(\alpha>0.67)$. For correction, the following criteria were used: one point for each correct answer, eight in total.

Another similar task was applied, presenting for instance, "anda - andou/olha -?" (walks - walked / looks -?), which involved inflectional morphology, also witheightitems. For correction, the same criteria were used: one point for each correct answer, eightin total.

2. Production of Neologism (Paula, 2007).

This task was originally developed by MarecBreton (2003) for French and later adapted into Brazilian Portuguese by Paula (2007). The task was designed to assess knowledge about derivational morphemes in Portuguese, using the technique of forming new morphologically complex words. For selecting the items proposed in the task, we consulted three Portuguese dictionaries, Houaiss (2001), Ferreira (1999), and Michaelis (1998), so we ruled out the possibility of asking the participants the formation of existing words in the language. The task consisted of a total of 20 items: 10 verbs by prefixation and 10 names formed by suffixation. The words were formed from words that have a high or medium frequency in the language. The instruction given to the child was: "Let's play a game: I'll give you a word, and you will invent words from the same family." For example, I say: "cadeira" (chair) and you must say how we could call a person who makes chairs, i.e., "cadeireiro" ("chairmaker").

\section{Assessment Ofphonological Awareness}

1. Spoonerism Test: - adapted by Cardoso-Martins, Haase and Wood, (1998) from the Phonological Batty Assessment developed by Frederickson, Frith, Reason 
The task is to make a quiz with the sounds of words. It was held in two parts, each containing three training items and ten experimental items: first, the student was asked to replace the initial sound of a word. For instance, "If I have the word gato (cat), how would this word be if I switched the sound of ' $g$ ' by ' $r$ '?" In the second part, we present a compound word changing the first sound of two words. The student was instructed to replace the first phoneme of the first word with the first phoneme of the second word. For instance, "in the compound word "green corn" if we change the ' $m$ ' for ' $v$ ' and the ' $v$ ' for ' $m$ ', how would the word be?" In the experimental items the examiner presents the compound words directly saying, for instance, how banana caturra would be. No feedback was given to the students' responses. For correction, the following criteria were used: in each part a point was given for each correct answer, covering ten points in total; the highest score in both parts was 20 points.

\section{Intelligent Assessment}

\section{Non-Verbal General Intelligence Test-}

TIG-NV (Tosi, 2008)

The aim of the test is to assess performances that are characteristic of non-verbal intelligence tests. It is a multiple-choice test, with 30 items, whose diversity of stimuli enables the analysis of brain functions that combine each other to enable the achievement of certain types of performance, such as spatial and mathematical reasoning, recognition memory, and others. The instrument in question presents good internal consistency coefficient index $(\alpha=0.89)$. The test was administered and corrected according to the instructions and procedures specified in the manual.

\section{Proceedings}

After the project was approved by the Research Ethics Committee of Universidade Salgado de Oliveira, parents were asked to sign the Informed Consent From (ICF). The criterion to include students in the survey was presenting the ICF signed by parents or guardians.

The students performed the tasks in the rooms suggested by the school. The tasks proposed by the TDE Subtest, the TIG-NV Intelligence Test, the Neologism Production Task, the Cloze Test, and the Text Comprehension Questionnaire were applied collectively for about 45 minutes. Only the tasks of Grammatical Analogy, Flexional Analogy, and the Spoonerism Test were applied in individual sessions, lasting about 15 minutes. The administration of the tasks was organized in three sessions. The choice of using different sessions was due to the amount of tasks and the possible fatigue of the students while performing them, so that the reliability of the answers was not compromised. In the first meeting the instruments that assessed reading were administered, in the second, the instruments that assessed phonological and morphological awareness, and intelligence was assessed in the last meeting.

\section{Results}

We started this section verifying mean, standard deviation, maximum and minimum scores obtained in the tasks, Skewness value, Kurtosis value, as well as the value of the standard error for Skewness and Kurtosis, according to the objective of this study, that are presented in Table 1.

A normal distribution was defined for variables with scores greater than -1.96 and lower than 1.96 (Dancey \& Reidy, 2006) resulting from the division of the skewness value by the standard error of skew ness and the value of kurtosis by the standard error of kurtosis. It is noteworthy that only the TDE reading variable did not present a normal distribution, so logarithmic transformations had to be performed in the TDE reading variable. After these modifications, all variables presented a normal distribution.

The results of descriptive statistics showed that the neologism scores presented a mean of 3.38, which showed that the task was very difficult for students. Next, we explored the relationship between reading words, writing, reading comprehension, non-verbal intelligence, and task metalinguistic skills. To verify whether there is a relationship between morphological awareness and the variables reading and text comprehension in Brazilian Portuguese, we performed a Pearson correlation between the variables of this study. Table 2 presents the analyses of correlations with data from the TDE reading variable already processed.

Table 2 shows that the variable reading, writing, spoonerism 1, and spoonerism 2 were significantly correlated with all the other variables. The variable Non-verbal Intelligence/TIG did not show a statistically significant correlation with the variable derivational morphology and neologism. The variable reading comprehension did not show a statistically significant correlation with the variable derivational morphology. The results of these analyzes indicated that the variable reading/TDE was significantly correlated with the variables inflectional morphology $(r=-0.49, p<0.01)$, 
derivational morphology $(r=-0.57, p<0.01)$, and neologism $(r=-0.43, p<0.01)$. The two spoonerism measures were significantly correlated with reading, $r=-0.74, p<$ 0.01 for spoonerism 1 , and $r=-0.70, \mathrm{p}<0.01$ for spoonerism 2 . The results of these analyses indicated that the variable derivational morphology was significantly correlated with reading $(r=-0.57, p<0.01)$, and the variable inflectional morphology also correlated significantly with reading $(r=-0.49, p<0.01)$. These negative scores should be interpreted as positive, because the logarithmic transformations imply aninversion of the data.
There was a significant correlation between the variable neologism and the variable reading comprehension $(r=$ $-0.32, p<0.01)$.

The theoretical model, which initially aims to investigate morphological awareness of the contribution for reading and for reading comprehension, was tested through linear regressions. Analyses were performed to test the contribution of derivational and inflectional grammatical analogy tasks and neologism-production tasks for reading and text comprehension, after controlling for non-verbal intelligence and phonological

Table 1

Descriptive, Skewness and Kurtosis Statistics

\begin{tabular}{lcccccccc}
\hline Tasks & Mean & S.D. & Max. & Min. & Skewness & S.D. Skw. & Kurtosis & S.D. Kur \\
\hline Age & 131.44 & 12.01 & 108.00 & 159.00 & 0.45 & 0.32 & -0.14 & 0.63 \\
Reading & 62.80 & 9.32 & 70.00 & 19.00 & -2.74 & 0.32 & 9.34 & 0.63 \\
$\begin{array}{l}\text { Non-verbal } \\
\text { intelligence }\end{array}$ & 89.98 & 8.79 & 108.00 & 75.00 & 0.47 & 0.32 & -0.63 & 0.63 \\
$\begin{array}{l}\text { Inflectional } \\
\text { morphology }\end{array}$ & 6.20 & 2.17 & 8.00 & 0.00 & -1.12 & 0.32 & 0.25 & 0.63 \\
$\begin{array}{l}\text { Derivational } \\
\text { morphology }\end{array}$ & 5.42 & 1.78 & 8.00 & 1.00 & -0.30 & 0.32 & -0.47 & 0.63 \\
$\begin{array}{l}\text { Neologism } \\
\text { Reading }\end{array}$ & 3.38 & 1.91 & 7.00 & 0.00 & -0.15 & 0.32 & -0.93 & 0.63 \\
comprehension & 6.92 & 2.42 & 11.00 & 0.00 & -0.65 & 0.32 & 0.44 & 0.63 \\
$\begin{array}{l}\text { Spoonerism 1 } \\
\text { Spoonerism 2 }\end{array}$ & 6.77 & 2.63 & 10.00 & 0.00 & -0.51 & 0.32 & -0.50 & 0.63 \\
\hline
\end{tabular}

Table 2

Bivariate Correlation (Pearson) between the Variables Log TDE/Reading, Writing, text Comprehension, Non-Verbal Intelligence and Metalinguistic Skills

\begin{tabular}{lccccccc}
\hline Variables & 2 & 3 & 4 & 5 & 6 & 7 & 8 \\
\hline Log TDE/reading & $0.25^{* *}$ & $-0.49^{* *}$ & $-0.57^{* *}$ & $0.43^{* *}$ & $-0.38^{* *}$ & $-0.74^{* *}$ & $-0.70^{* *}$ \\
Non-verbal intelligence & & $0.28^{* *}$ & 0.14 & 0.10 & $0.24^{*}$ & $0.44^{* *}$ & $0.38^{* *}$ \\
Inflectional & & & $0.25^{*}$ & $0.31^{*}$ & $0.34^{* *}$ & $0.53^{* *}$ & $0.50^{* *}$ \\
Derivational & & & & $0.38^{* *}$ & 0.11 & $0.47^{* *}$ & $0.55^{* *}$ \\
Neologism & & & & $0.32^{* *}$ & $0.35^{* *}$ & $0.32^{*}$ \\
Comp text & & & & & $0.34^{* *}$ & $0.36^{* *}$ \\
Spoon 1 & & & & & & $0.72^{*}$ \\
Spoon 2 & & & & & & \\
\hline
\end{tabular}

Note. All correlations in bold were significant $\left(^{*}\right)$ at $0.05 ;(* *)$ significant correlations at 0.01 . Negative correlation between TDE and reading must be interpreted as positive, once logarithmical transformations invert signs. 
awareness measures that were significant in the correlations performed.

The results presented in Table 3 show that after the introduction of the non-verbal intelligence variable and the spoonerism task 1, respectively controlled, the task of derivational morphological awareness explained about $6 \%$ of the reading ability variance. When the hierarchical regression switched the spoonerism 1 task for the spoonerism 2 task, the derivational morphological processing explained $5 \%$ of the variance.

The results of these analyzes showed that the independent contribution of derivational morphological awareness to reading when it entered regression after spoonerism task 1 ( $\beta=0.62 ; p<0.05)$ was higher than when it entered after spoonerism task $2(\beta=0.55$; $p$ $<0.05)$. The results also showed that after the inclusion of the non-verbal intelligence variable and the spoonerism task 2 , the neologism contributed significantly to reading variance $(\beta=0.57 ; p<0.05)$.

Finally, after controlling for non-verbal intelligence, spoonerism task 1 explained $48 \%$ of reading variance when derivational morphological awareness explained $6 \%$. The same was observed for spoonerism task 2, which explained $43 \%$. These steps explain a significant percentage of reading variance. With regard to the neologism task, Table 3 shows that after controlling for non-verbal intelligence, the spoonerism task 2 explained $46 \%$ of the variance when the neologism task explained $4 \%$. Therefore, neologism also contributed independently $(\beta=0.57 ; p<0.05)$ for the reading ability.

\section{Discussion}

The literature has indicated that metalinguistic skills are important for reading and text comprehension. This has been demonstrated by statistically significant correlations between reading and phonological and morphological awareness tasks in Brazilian Portuguese and other alphabetic languages. (Capovilla \& Capovilla, 2000; Carlisle, 1995; Mota \& et al 2011). In this study, in line with the studies mentioned above, in general, the correlations showed that children with better scores in metalinguistic skills were children with better

Table 3

Linear Regressions Considering Criteria Variables TDE/Reading and Text Comprehension and Explicative Variables Non-Verbal Intelligence, Morphologic Awareness, and Spoonerism

\begin{tabular}{|c|c|c|c|c|c|c|c|}
\hline \multirow{3}{*}{ Steps } & \multicolumn{4}{|c|}{ Variables } & \multicolumn{3}{|c|}{ Criteria } \\
\hline & \multirow[b]{2}{*}{ Explicative variables } & \multicolumn{3}{|c|}{ Reading } & \multicolumn{3}{|c|}{ Text Comprehension } \\
\hline & & $\mathrm{R}^{2}$ & $\mathrm{R}^{2} \Delta$ & $\mathrm{P}$ & $\mathrm{R}^{2}$ & $\mathrm{R}^{2} \Delta$ & $\mathrm{P}$ \\
\hline 1. & Non-verbal intelligence & 0.06 & 0.06 & 0.06 & 0.06 & 0.06 & 0.08 \\
\hline 2. & Spoonerism 1 & 0.55 & 0.48 & $0.01 * *$ & 0.13 & 0.07 & $0.05^{*}$ \\
\hline 3. & Derivational morphology & 0.61 & 0.59 & $0.01 * *$ & 0.13 & 0.01 & 0.70 \\
\hline 3. & Inflectional morphology & 0.57 & 0.01 & 0.22 & 0.16 & 0.02 & 0.24 \\
\hline 2. & Spoonerism 2 & 0.50 & 0.43 & $0.01 * *$ & 0.14 & 0.08 & $0.03 *$ \\
\hline 3. & Derivational morphology & 0.55 & 0.05 & $0.02^{* *}$ & 0.14 & 0.10 & 0.44 \\
\hline 3. & Inflectional morphology & 0.52 & 0.02 & 0.12 & 0.17 & 0.02 & 0.26 \\
\hline 1. & Non-verbal intelligence & 0.06 & 0.06 & 0.08 & 0.06 & 0.06 & 0.08 \\
\hline 2. & Spoonerism 1 & 0.53 & 0.51 & $0.01^{* *}$ & 0.13 & 0.07 & $0.05^{*}$ \\
\hline 3. & Neologism & 0.57 & 0.54 & 0.06 & 0.18 & 0.05 & 0.09 \\
\hline 2. & Spoonerism 2 & 0.52 & 0.46 & $0.01 * *$ & 0.14 & 0.08 & $0.04 *$ \\
\hline 3. & Neologism & 0.57 & 0.04 & $0.03^{*}$ & 0.20 & 0.05 & 0.09 \\
\hline
\end{tabular}

$*_{\mathrm{p}}<0.01 / *^{*} \mathrm{p}<0.001$ 
scores in isolated-word reading and also in reading comprehension.

The specific theoretical question in which we hypothesized that morphological awareness still contributes to reading after controlling for the effect of the variables non-verbal intelligence and phonological awareness was corroborated by our data. Based on the results of linear regression analyses that investigated the contribution of morphological and phonological awareness to reading ability, we can say that both morphological awareness and phonological awareness contribute to reading words, and that the scores of neologism and derivational morphology tasks contribute to word reading after controlling for the variable phonological awareness.

The results of this study, however, showed no independent contribution of inflectional morphology for word reading and text comprehension, although the variable reading has shown a significant correlation with inflectional morphology and neologism. There are some possible explanations for this, as evidenced by Tong et al. (2011). According to these authors, at this stage of development, mainly from the intermediate years of elementary school, the students will come across increasingly complex words. And this complexity is more associated with derivational morphology than with inflectional morphology, which is more developed at this stage of learning and, therefore, can no longer be contributing much to reading acquisition. Another explanation for this fact may be the bias of the test used in this study. In Table 1, the results show a mean of 6.2 in relation to the eight items of the inflectional morphology task, which in turn, suggests that the test may be inconsistent for evaluating the inflectional morphological awareness of these students because it is too easy a task for them. It would be important that future studies verified these two considerations using more complex inflectional morphology tests for samples in this age group and including younger children in the sample.

The result of the present study shows that morphological awareness contributes toword reading. This finding corroborates the results of several studies conducted in different orthographies, but which not always used all the necessary controls (Carlisle, 1995; Mota, Anibal \& Lima, 2009). The results are not in line with those of Justi and Roazi (2012). A possible explanation for this discrepancyis the fact that Justi and Roazzi have used only one word-analogy test to assess morphological awareness with items that were different from those used in this study. As we have mentioned, there are differences in the development of derivational and flectional morphology among students throughout their education and this difference seems to affect reading and writing also in a different way (Casalis \& LouisAlexander, 2000; Tong \& et al, 2011.).

With regard to reading comprehension we did not find an independent contribution to morphological awareness. The results of the correlations showed that students who performed better in reading comprehension tasks are those who had good scores in neologism and flectional morphological awareness. Therefore, the results of this correlation found in this study suggest that morphological awareness contributes to reading comprehension. However, in relation to the regression results, after controlling for intelligence and phonological awareness, morphological awareness no longer contributed to reading comprehension independently. The question that arises is: why did not morphological awareness contribute to reading comprehension in this study? Is it possible that the contribution of morphological awareness to text comprehension in the Portuguese language is mediated by word reading? In this case, the learner would use the knowledge of morphology to recognize the words in the text, which in turn would help to integrate the text and to complete the process of understanding. It is important that future studies explore this hypothesis.

\section{Conclusion}

The main issue raised in this study was whether, after controlling for non-verbal intelligence and phonological awareness, morphological awareness continues to contribute to reading and text comprehension in Brazilian Portuguese. The study was based in several authors, such as Deacon and Kirby (2010); Nunes and Bryant (2006); and Carlisle (1995), among others who have pointed out the important role of morphological awareness in reading acquisition.

The results of this study suggest that morphological awareness contributes to word reading, in line with previous studies that indicate this relationship (Mota, 2008; Carlisle, 1995; Tong et al., 2011). These results reinforce the need for programs that encourage morphological processing in the development of reading and reading comprehension.

We need to point out the limitations of the methodology of this study that can be solved in the future, such as including more reading measures such 
as reading fluency and other reading comprehension measures. We also need to seek other inflectional morphology measures that better discriminate age groups after the fourth year of elementary school, this may help elucidate the differences between the results of regressions in studies already seen in the literature.

Another limitation was the sample size. Future studies should use larger samples, increasing the number of schools investigated. Large samples allow the testing of models by statistical means such as structural equation models that can investigate how these different variables interact and contribute not only to word reading but also to reading comprehension.

This study draws attention to the importance of creating standardized instruments to assess metalinguistic skills in Brazilian students, once the lack of these instruments hinders investigations that aim at better understanding the reading processes.

\section{References}

Bryant, P., \& Bradley, L. (1987). Problemas de leitura na criança (I. C. S. Ortiz, Trad.). Porto Alegre: Artes Médicas. (original publicado em1985).

Cardoso-Martins, C., Haase, V. G., \& Wood, G. (1998). Bateria de testes de habilidades fonológicas adaptada daphonological Assement Battery. Manuscrito não publicado.

Carlisle, J. (1995). Morfhological awareness and early reading achievement. In L. Feldman (Ed.) Morphological aspects of language processing, (pp.189-211). Hillsdale: Lawrence Erlbaum Associates.

Carlisle, J. (2000). Awareness of the structure and meaning of morphologically complex words: impact on reading. Reading \& Writing: an Interdisciplinary Journal, 12, 169-190. Retrieved from http://link.springer. com/article/10.1023\%2FA\%3A1008131926604

Casalis, S., \& Louis-Alexandre, M. F. (2000). Morphological analysis, phonological analysis and learnig to read French: a longitudinal study. Reading and Writing, 12, 303-335. Retrieved from http://link.springer.com/article/10.1023\%2FA\% 3A1008177205648

Capovilla, A., \& Capovilla, F. (2000). Efeitos do treino de consciência fonológica em crianças com baixo nível socioeconômico. Psicologia: Reflexão e Crítica, 13(1),07-24. doi: 10.1590/ S0102-79722000000100003
Dancey, C. P., \& Reidy, J. (2006). Estatística sem matemática para psicologia. Porto Alegre: Artmed.

Deacon, S., \& Bryant, P. (2005). What Young children do and do not Know About the spelling of inflections and derivations. Developmental Science, 8(6), 583-594. Retrieved from http://www.ncbi.nlm. nih.gov/pubmed/16246249

Deacon, S., Parrila, S., \& Kirby, J, (2010). The effects of morphological instruction on literacy skills: A systematic review of the literature. Review of Educational Research, 80, 144-179. doi: 10.3102/0034654309359353

Justi, C. N. G., \& Roazzi, A. (2012). A contribuição de variáveis cognitivas para a leitura e a escrita no português brasileiro. Psicologia: Reflexão e Crítica, 25(3), 605-614. doi: 10.1590/S0102-79722012000300021

Ferreira, A. G. (1999). Dicionário de latim-português. Porto: Porto Editora.

Houaiss, A. (2001). Dicionário Honaiss eletrônico da Lingua portuguesa. São Paulo: Objetiva.

Michaelis, (1998). Moderno dicionário da Lingua Portuguesa. São Paulo: Companhia Melhoramentos.

Mota, M. M. P. E. (2008). Algumas considerações a respeito do que as crianças sabem sobre a morfologia derivacional. Interação em Psicologia, 12(1), 115-123. doi: $10.5380 /$ psi.v12i1.7452

Mota, M., Anibal, A., \& Lima, S. (2008). A morfologia derivacional contribui para a leitura e escrita no português? Psicologia: Reflexão e Crítica, 21(2), 311-318. Retrieved from http://www.redalyc.org/ articulo.oa?id $=18821217$

Mota, M., Lisboa, R., Dias, J., Gontijo, R., Paiva, N., Mansur-Lisboa, S. F., Silva, D. A., \& Santos, A. A. A.(2009). Relação entre consciência morfológica e leitura contextual medida pelo teste de cloze. Psicologia: Reflexão e Crítica, 22(2), 223-229. doi: 10.1590/ S0102-79722009000200008

Mota, M. (2009). O papel da consciência morfológica para a alfabetização em leitura. Psicologia em Estudo, 14(1),159-166. Retrieved from http://www.scielo. br/pdf/pe/v14n1/a19v14n1.pdf

Mota, M. Dias, J.; Mansur-Lisboa, S. F.; Paiva, N.; Silva, D. A., \& Besse, A (2011). Consciência morfológica: Aspectos cognitivos da linguagem e 
reconhecimentos de palavras. Interação em Psicologia, 15(1), 21-26. doi: 10.5380/psi.v15i1.15654

Moura, I. C. S. (2006) Compreensão da leitura textual de alunos com sindrome de Asperger: Um estudo exploratório (Dissertação de mestrado). Universidade Gama Filho. Rio de Janeiro.

Marec-Breton, N (2003). Les traitemant morfhologiques dans l' apprentissage de la lecture (Unpublished Doctorat de Pshychologie). Université de Rennes 2, Reenes.

Nunes, T., Bindman, M., \& Bryant, P. (1997). Morphological strategies: Developmental stages and processes. Developmental Psychology, 33(4), 637649. Retrieved from http://bobhall.tamu.edu/ epsy602/Topics/Articles/Bryant1997.pdf

Nunes, T., \& Bryant, P. (2006). Improving literacy by teaching morphemes. London: Routledge.

Santos, A. A. A. (2005). O cloze na avaliação da compreensão em leitura com alunos de $5^{a}$ a $8^{a}$ série. Manuscrito não publicado.

Paula, F. V. (2007). Conhecimento morfologico implícito e explícito na linguagem escrita (Tese de Doutorado). Universidade de São Paulo, São Paulo.
Silva, D. A., \& Mota, M. (2009). Déficits nas habilidades metalinguísticas em crianças com dificuldades na leitura. Psicologia em Pesquisa (UFJF), 3(2),110-118. Retrieved from http:// pepsic.bvsalud.org/scielo.php?pid $=$ S1982$-12472009000200009 \&$ script $=$ sci_arttext

Stein, L. (1994). Teste de desempenho escolar. São Paulo, SP: Casa do psicólogo.

Tong, X., Deacon, S., Parrila, S., \& Kirby, J. (2011). Morphological awareness: A key to understanding poor reading comprehension in english. Journal of Educational Psychological Association, 103(3), 523534. Retrieved from http://psycnet.apa.org/index. cfm?fa=buy.option ToBuy\&id=2011-12257-001

Tosi, S. M. (2008). TIG-NV - Teste de Inteligência Geral não verbal- Instrumento de avaliação psicológica e neuropsicológica ( $3^{\text {a }}$ ed.). São Paulo: Casa do Psicólogo

Recebido: 14/08/2014

Primeira reformulação: 03/03/2015 Aprovado: 19/03/2015 
Nota dos autores:

Ambos os autores agradecem à FAPERJ por financiar suas atividades. Este estudo é parte integrante da tese de doutorado do primeiro autor.

Sobre os autores:

Pedro Viana de Freitas Junior é psicólogo, mestre, doutorando em Psicologia pela Universidade Salgado de Oliveira, bolsista Professor tutor CEAD - UNIRIO.

E-mail:pedrovjr@ig.com.br

Márcia Maria Peruzzi Elia da Mota é psicóloga, doutora em Psicologia pela Universidade de Oxford na Inglaterra, professora titular da Universidade Salgado de Oliveira e da UERJ, e bolsista de Produtividade Nível 2 do CNPq. E-mail:mmotapsi@gmail.com

Contato com os autores:

Secretaria do Mestrado e Doutorado em Psicologia

Márcia Maria Peruzzi Elia da Mota

E-mail:mmotapsi@gmail.com

Universidade Salgado de Oliveira - UNIVERSO - Campus Niterói

Rua Mal. Deodoro, 263 - Centro - Niterói/RJ

CEP: $24030-060$. 